\title{
Green Noctiluca scintillans: a dinoflagellate with its own greenhouse
}

\author{
Per J. Hansen ${ }^{1, *}$, Lilibeth Miranda ${ }^{2,3}$, Rhodora Azanza ${ }^{2}$ \\ ${ }^{1}$ Marine Biological Laboratory, University of Copenhagen, Strandpromaden 5, 3000 Helsingør, Denmark \\ ${ }^{2}$ The Marine Science Institute, University of the Philippines, Diliman, Quezon City 1101, Philippines \\ ${ }^{3}$ Present address: University of Connecticut, Department of Marine Sciences, 1080 Shennecossette Rd, Groton, \\ Connecticut 06340, USA
}

\begin{abstract}
The effect of irradiance on photosynthesis of the green form of the dinoflagellate Noctiluca scintillans was studied. Photosynthesis, measured in cells collected from the field and without the addition of prey, increased with irradiance to ca. $200 \mathrm{ng} \mathrm{C}$ cell-1 $\mathrm{d}^{-1}$ at an irradiance of $\sim 250$ to $300 \mu \mathrm{mol}$ photons $\mathrm{m}^{-2} \mathrm{~s}^{-1}$. N. scintillans cells were observed to prey and grow actively on a number of different algae, including the dinoflagellate Pyrodinium bahamense var. compressum which produces paralytic shellfish toxin. However, in all cases, $N$. scintillans lost its endosymbionts when grown in the laboratory for more than $3 \mathrm{wk}$ and became colourless, irrespective of food item, concentration and irradiance. A factor necessary for endosymbiont growth was apparently missing, which was not provided to them by $N$. scintillans when fed the selected prey types. Thus, further experiments were carried out with freshly collected organisms. The growth rate of $N$. scintillans when grown without prey was 0.058 and $0.14 \mathrm{~d}^{-1}$ at irradiances of 45 and $150 \mu \mathrm{mol}$ photons $\mathrm{m}^{-2} \mathrm{~s}^{-1}$ at a light:dark cycle of $12: 12 \mathrm{~h}$ and a temperature of $26^{\circ} \mathrm{C}$. When supplied with $P$. bahamense as food, $N$. scintillans increased its growth rate to 0.09 and $0.24 \mathrm{~d}^{-1}$, at irradiances of 45 and $150 \mu \mathrm{mol}$ photons

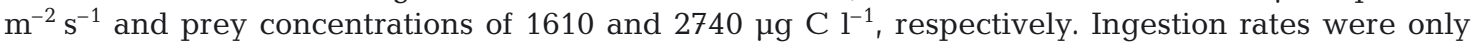
measured at $150 \mu \mathrm{mol}$ photons $\mathrm{m}^{-2} \mathrm{~s}^{-1}$. At this irradiance, the ingestion rate increased linearly with prey concentration and showed no signs of satiation at a prey concentration of $\sim 2700 \mu \mathrm{g} \mathrm{Cl}^{-1}$. A comparison of the contribution of photosynthesis and phagotrophy to the carbon metabolism revealed that phagotrophy only contributed significantly $(30 \%)$ to the direct growth of the green $N$. scintillans at an irradiance of $150 \mu \mathrm{mol}$ photons $\mathrm{m}^{-2} \mathrm{~s}^{-1}$, when the prey concentration was very high. Clearance decreased with prey concentration, from $\sim 0.06 \mathrm{ml} \mathrm{N}$. scintillans ${ }^{-1} \mathrm{~d}^{-1}$ at $25 \mu \mathrm{g} \mathrm{C}^{-1}$ to $\sim 0.03 \mathrm{ml}$ $N$. scintillans ${ }^{-1} \mathrm{~d}^{-1}$ at a prey concentration of $2740 \mu \mathrm{g} \mathrm{Cl}^{-1}$. This indicates that $N$. scintillans, when it occurs at bloom concentrations in nature $(1$ to 10 cells ml-1 $)$, may have a significant impact on the bloom dynamics of $P$. bahamense var. compressum.
\end{abstract}

KEY WORDS: Green Noctiluca scintillans $\cdot$ Pyrodinium bahamense $\cdot$ Photosynthesis $\cdot$ Food uptake Resale or republication not permitted without written consent of the publisher

\section{INTRODUCTION}

Noctiluca scintillans (Macartney) is a large and conspicuous dinoflagellate, which is common in coastal areas worldwide (Elbrächter \& Qi 1998). The most widely spread form of $N$. scintillans is completely hetertrophic and is an omnivorous feeder that ingests a wide range of prey, including phytoplankton, microzooplankton, mesozooplankton and their eggs (Enomoto 1956, Prasad 1958, Chen \& Qi 1991, Buskey 1995). However, in the tropical to sub-tropical areas of Southeast Asia (e.g. Thailand, India, Philippines, New
Guinea), a green form of N. scintillans is found. This variety harbours thousands of free-swimming cells of the prasinophyte Pedinomonas noctilucae inside itself (Sweeney 1976; Fig. 1).

Despite the fact that the green form of Noctiluca scintillans regularly forms massive blooms in many areas of Southeast Asia (see review by Elbrächter \& Qi 1998), our knowledge of its biology is very sparse; it is, in fact, restricted to a single paper published by Sweeney in 1971. In laboratory studies she demonstrated that the green $N$. scintillans could survive and divide in the light without the addition of food for at 
least 1 mo. In darkness, however, the symbiotic flagellate disappeared and the $N$. scintillans cells died within a few days unless a food organism, Dunaliella tertiolecta (Butcher), was added. Thus, her results indicate that $N$. scintillans either incorporates endosymbionts into food vacuoles or utilizes their photosynthetic products as nutrition. Long-continued growth of $N$. scintillans in the light seems to require the presence of prey, since the symbiotic flagellates were gradually lost under all culture conditions assayed by Sweeney (1971). Thus, the instability of the symbiosis between Pedinomonas noctilucae and N. scintillans suggests that the symbiotic relationship represents a primitive stage in the establishment of symbiosis.

While the study by Sweeney (1971) gave some insight into the symbiotic relationship between Noctiluca scintillans and Pedinomonas noctilucae, it provided no rates on either photosynthesis of the endosymbionts or ingestion of prey by $N$. scintillans. Thus, whether the green $N$. scintillans primarily functions as a phototroph or as a heterotroph is unknown. Also, the importance of $N$. scintillans as a grazer in the areas where it blooms is unknown.

In the Philippines, the only organism that has caused major toxic red tides is the dinoflagellate Pyrodinium bahamense var. compressum (Böhm). In Manila Bay, P. bahamense blooms and associated paralytic shellfish poisonings (PSPs) were first experienced in 1988, and since 1991 blooms occur almost yearly. It has caused vast losses in the shellfish industry, amounting to US $\$ 300000 \mathrm{~d}^{-1}$ during the height of the red tide scare (Corrales \& Maclean 1995). Recently, it has been observed that dense populations of the green Noctiluca (up to 1 to 10 cells $\mathrm{ml}^{-1}$ ) often succeed blooms of $P$. bahamense var. compressum in Manila Bay (Azanza \& Miranda 2001). Thus, N. scintillans might play a significant role in the termination of $P$. bahamense blooms in this area.

The aim of the present investigation was to quantify photosynthesis, food uptake and growth of the green Noctiluca scintillans in monocultures and in mixed cultures with other algae, with special emphasis on Pyrodinium bahamense var. compressum.

\section{MATERIALS AND METHODS}

Collection, culture and carbon content of the organisms. The dinoflagellates Pyrodinium bahamense var. compressum and Akashiwo sanguinea (Hirasaka) (=Gymnodinium sanguineum) with cell dimensions of 50 to 65 and 40 to $75 \mu \mathrm{m}$, respectively, were isolated from Manila Bay, Philippines (Corrales \& Hall 1993). The prasinophyte Tetraselmis tetrahele (G. S. West), with a cell dimension of 10 to $16 \mu \mathrm{m}$, was collected from Bolinao, Pangasina, Northern Philippines and provided by Ms. Helen Bangi of the Marine Invertebrate Research Laboratory (UP-MSI). These algae were grown in $\mathrm{f} / 2$ medium based on $36 \mathrm{psu}$ seawater at a temperature of $24 \pm 2{ }^{\circ} \mathrm{C}$ following a light:dark cycle of 12:12 h. Illumination was provided by cool white fluorescent lamps at an irradiance of $150 \mu \mathrm{mol}$ photons $\mathrm{m}^{-2} \mathrm{~s}^{-1}$. On several occasions during the years 2000 and 2001 green Noctiluca scintillans cells were collected from the western part of Manila Bay with a plankton net (mesh size $20 \mu \mathrm{m}$ ), poured into 21 polycarbonate bottles and immediately brought back to the laboratory. At the laboratory, $N$. scintillans cells gathered at the periphery of the containers close to the surface, from where they were collected using a Pasteur pipette and transferred to glass beakers containing f/2 medium. $N$. scintillans cells were subsequently transferred 4 to 5 times to fresh f/2 medium, which in the end resulted in a suspension containing only $N$. scintillans cells that was used for the experimental work. Cellular carbon content of N. scintillans and P. bahamense var. compressum was determined by filtering cell suspensions onto precombusted GF/C filters. These filters were dried at $65^{\circ} \mathrm{C}$ for $48 \mathrm{~h}$ and analyzed for particulate organic carbon (POC) using a CHN elemental analyzer (Model NA 1500, Fisons Instruments).

Attempts were made to grow the green form of Noctiluca scintillans in laboratory cultures in monocultures and mixed cultures with selected algal species. These experiments were carried out in $72 \mathrm{ml}$ tissue culture flasks at an irradiance of $150 \mu \mathrm{mol}$ photons $\mathrm{m}^{-2} \mathrm{~s}^{-1}$. A stock suspension of $N$. scintillans was prepared and mixed with unialgal cultures of different prey species. This resulted in experimental flasks with a final concentration of $\sim 1$ N. scintillans $\mathrm{ml}^{-1}$, and 100, 100 and 760 cells ml ${ }^{-1}$ of Pyrodinium bahamense, Akashiwo sanguinea and Tetraselmis tetrahele, respectively.

The experimental flasks were placed on a plankton wheel rotating at $1 \mathrm{rpm}$ to keep the algae in suspension and homogeneously distributed. Noctiluca scintillans cells were counted directly from the bottles every 2nd day under a dissecting microscope for the duration of the experiments (up to $10 \mathrm{~d}$ ). This was possible because $N$. scintillans cells were positively buoyant. For the enumeration of prey cells, subsamples $(4 \mathrm{ml})$ were taken every 2nd day. The culture flasks were gently shaken before withdrawing samples to disrupt any aggregates of cells that had formed. Fresh f/2 medium was added to replace the sampled volume. The samples were fixed in Lugol's solution (final concentration: 1\%) and counted in an inverted microscope.

Because our attempts to grow Noctiluca scintillans failed (see 'Results'), we decided to carry out the remaining part of this study using freshly collected N. scintillans cells. 
Experiments on Noctiluca scintillans photosynthesis. Photosynthesis of $N$. scintillans cells was measured using a modification of the 'single cell' method (Stoecker et al. 1988, Skovgaard et al. 2000). A suspension containing 10 N. scintillans cells ml ${ }^{-1}$ was prepared from dilution of a stock suspension and poured into scintillation vials $(22 \mathrm{ml})$. $\mathrm{A} \mathrm{NaH}^{14} \mathrm{CO}_{3}^{-}$ stock solution (specific activity $100 \mu \mathrm{Ci} \mathrm{ml} \mathrm{m}^{-1}$ ) was added to each vial, resulting in a specific activity of $\sim 1.0 \mu \mathrm{Ci} \mathrm{ml}{ }^{-1}$, and afterwards the vials were incubated on a plankton wheel (1 rpm) for 1 to $6 \mathrm{~h}$ (see below), starting 1 to $3 \mathrm{~h}$ after the onset of the light period. The vials were always accompanied by parallel dark vials, which were treated likewise, but wrapped in aluminum foil. After incubation, specific activity of the medium was measured by transferring $100 \mu \mathrm{l}$ from each vial to new vials containing $200 \mu \mathrm{l}$ phenylethylamine. The amount of fixed ${ }^{14} \mathrm{C}$ was measured by transferring $3 \mathrm{ml}$ to each of 4 to 6 vials, which received $3.0 \mathrm{ml}$ of $10 \%$ acetic acid in methanol to remove all inorganic C. These vials were dried overnight at $60^{\circ} \mathrm{C}$, and afterwards the residue was re-dissolved with $2 \mathrm{ml}$ of distilled water. Finally, $10 \mathrm{ml}$ of Packard Insta-Gel Plus scintillation flour were added to all vials (including those for specific activity), and activity was measured using a Packard 1500 Tri-Carb liquid scintillation counter analyzer with automatic quench correction. Calculations of photosynthetic rates were based on Parsons et al. (1984). Dissolved inorganic carbon content was measured with a 225-Mk3 infrared gas analyzer (Analytic Development).

In the first set of experiments using this technique, the linearity of ${ }^{14} \mathrm{C}$ uptake for freshly collected Noctiluca scintillans cells over time were tested by incubating triplicate vials for 1, 2, 3, 4, 5 and $6 \mathrm{~h}$. After this test, we carried out a second set of experiments using this technique to determine photosynthesis at 6 different irradiances using incubation times of 1 to $3 \mathrm{~h}$. All experiments were carried out in triplicate.

The functional and numerical response of Noctiluca scintillans when fed Pyrodinium bahamense. The functional and numerical response of $N$. scintillans was studied when fed $P$. bahamense var. compressum at 2 irradiances. In the first set of experiments, $N$. scintillans (1 cell $\mathrm{ml}^{-1}$ ) was incubated with different initial prey concentrations $(0,5,10,25,50,75,100,250$ and 500 cells ml $\mathrm{m}^{-1}$ ) at an irradiance of $150 \mu \mathrm{mol}$ photons $\mathrm{m}^{-2} \mathrm{~s}^{-1}$. Based on the results obtained in this set of experiments, a second set of experiments was carried out, this time at a lower irradiance of $45 \mu \mathrm{mol}$ photons $\mathrm{m}^{-2} \mathrm{~s}^{-1}$ and initial prey concentrations of $0,5,25,75$ and 250 cells $\mathrm{ml}^{-1}$. Prior to the experiments, N. scintillans was acclimated to the prey concentrations and irradiances for $2 \mathrm{~d}$. The initial concentrations of $P$. bahamense and $N$. scintillans in these experiments

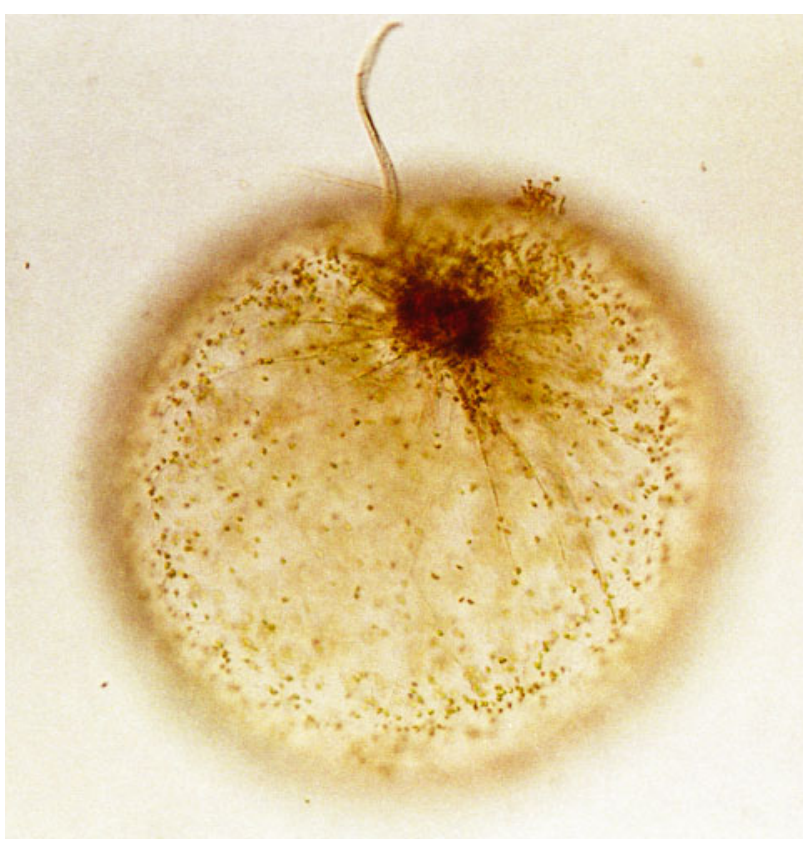

Fig. 1. Noctiluca scintillans from Manila Bay, Philippines Note the large number of free-swimming cells of the endosymbiotic prasinophyte Pedinomonas noctilucae inside the N. scintillans cell

were made by dilution of stock suspension with known cell densities. Control experiments with unialgal cultures of $P$. bahamense were carried out for all test concentrations. All experiments were carried out in $72 \mathrm{ml}$ tissue culture flasks with 4 replicates. N. scintillans and $P$. bahamense cells were quantified every 2 nd day as previously described in the section entitled 'Collection, culture and carbon content of the organisms'.

Growth $(\mu)$ of Noctiluca scintillans, measured as the change in cell number over time, was computed using the formula:

$$
\mu=\left[\ln \left(N_{t_{1}} / N_{t_{0}}\right)\right] t^{-1}
$$

where $N_{t_{0}}=$ concentration of cells at time $0\left(\right.$ cells ml $\left.{ }^{-1}\right)$, $N_{t_{1}}=$ concentration of cells at time $1\left(\right.$ cells ml $\left.{ }^{-1}\right)$, and $t=$ the duration of each experiment (d). Ingestion rate of Noctiluca was determined from the reduction in prey concentrations over $48 \mathrm{~h}$ periods as compared to the control cultures, according to Jakobsen \& Hansen (1997). The ingestion rate $U$ was estimated using the following 2 equations:

$$
\begin{gathered}
\mathrm{d} x / \mathrm{d} t=\mu_{x} x-U y \\
\mathrm{~d} y / \mathrm{d} t=\mu_{y} y
\end{gathered}
$$

where $(x)$ is ingested by grazer $(y)$. It was assumed that the grazer $(y)$ grows exponentially with the rate constant of $\mu_{y}$ and that the prey $(x)$ grows with the rate constant of $\mu_{x}$. The mortality due to grazing is $U_{y^{\prime}}$ 
where $U$ (dimension $x / y / t$ ) is the per capita ingestion rate, which is independent of $x$. As the solution to establish the value of $\mu$ is intractable, the ingestion rate $(U)$ was iteratively calculated with time on a computer, allowing steps of $1 \mathrm{~h}$. Clearance rate, the volume of water swept clear of Pyrodinium bahamense cells, was calculated as: $C=U(x) / x$.

\section{RESULTS}

\section{Attempts to grow the green form of Noctiluca scintillans}

We where able to keep and grow the green Noctiluca scintillans in monoculture using the f/2 growth medium for at least $2 \mathrm{wk}$ (Fig. 2). The cultures increased typically in cell concentration from 1 to 2 cells ml $\mathrm{m}^{-1}$ over a $2 \mathrm{wk}$ period at an irradiance of $150 \mu \mathrm{mol}$ photons $\mathrm{m}^{-2}$ $\mathrm{s}^{-1}$, and the $N$. scintillans cells contained many endosymbionts. However, if incubated for longer period, the N. scintillans cells lost their endosymbionts and slowly died off (data not shown).

When supplied with prey the growth/survival response of Noctiluca scintillans depended on the prey species offered (Fig. 2). N. scintillans died out between Days 4 and 6 when fed Tetraselmis tetrahele, coinciding
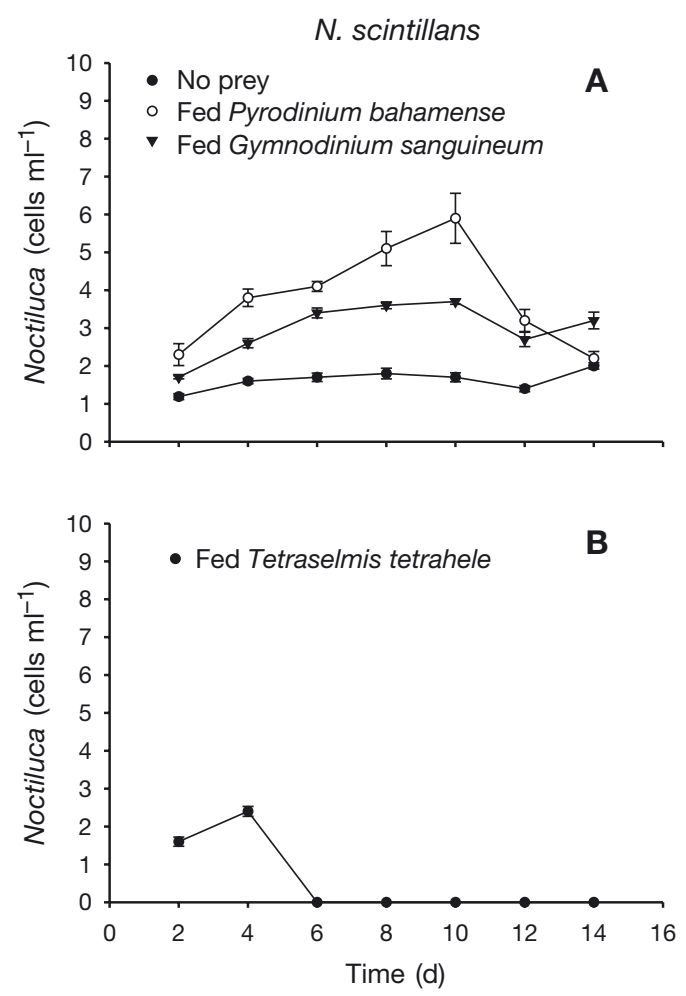

with very high cell concentrations of this alga. $N$. scintillans did better when Pyrodinium bahamense or Akashiwo sanguinea were offered as food, and it grew from an initial concentration of $1 \mathrm{cell} \mathrm{m}^{-1}$ to reach cell densities of 3.8 and 6 cells ml ${ }^{-1}$, respectively, after $10 \mathrm{~d}$ of incubation. However, in the following days the growth of the $N$. scintillans stopped, and in some cases cell numbers even declined. This coincided with the loss of endosymbionts. We observed long-term growth (several months) of the $N$. scintillans itself using $P$. bahamense as prey, but the endosymbionts were always lost (data not shown).

\section{Photosynthesis and carbon content of Noctiluca scintillans grown without prey}

The ${ }^{14} \mathrm{C}$ uptake by Noctiluca scintillans was linear within the studied timeframe of $5 \mathrm{~h}$ (Fig. 3A), and a maximum incubation time of $3 \mathrm{~h}$ was selected for further experiments. Photosynthesis (P) of N. scintillans increased with increasing irradiance (Fig. 3B), reaching $\sim 17 \mathrm{ng} \mathrm{C} \mathrm{cell}^{-1} \mathrm{~h}^{-1}$ at an irradiance of $300 \mu \mathrm{mol}$ photons $\mathrm{m}^{-2} \mathrm{~s}^{-1}$, which corresponds to $200 \mathrm{ng} C$ cell $^{-1} \mathrm{~d}^{-1}$ (light:dark 12:12 h). No saturation of photosynthesis was observed. The carbon content of $N$. scintillans was 410 ng C cell-1 (Table 1).
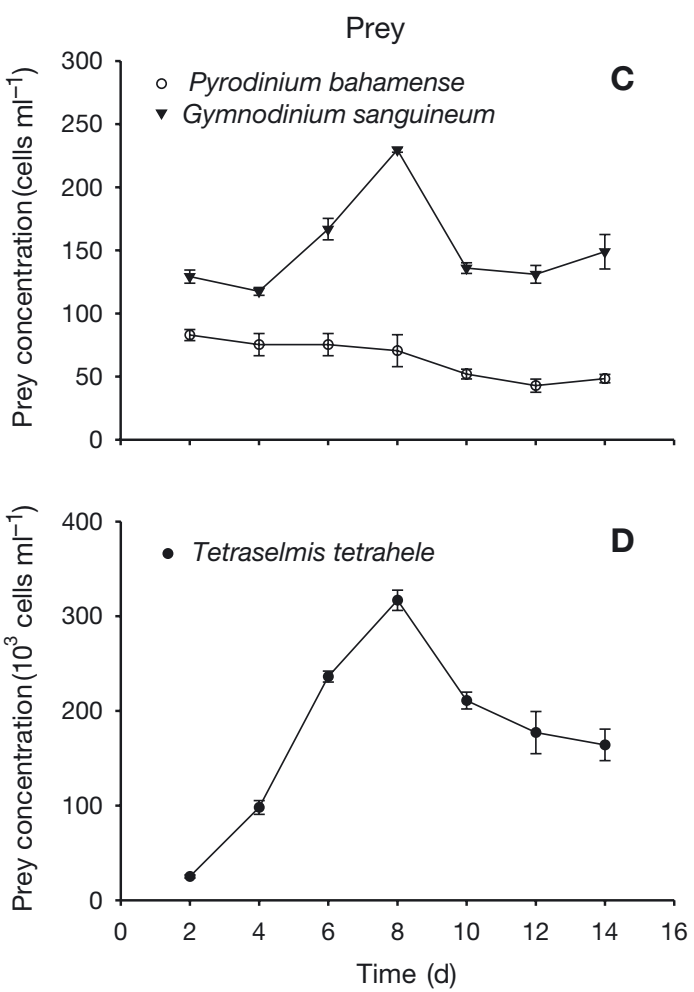

Fig. 2. Noctiluca scintillans. (A,B) Growth/survival responses when grown alone or with prey in mixed cultures during a 2 wk incubation in the laboratory. $(\mathrm{C}, \mathrm{D})$ Growth/survival responses of the prey in the mixed cultures. Data points represent means $\pm 1 \mathrm{SE}(\mathrm{n}=3)$ 
Table 1. Carbon contents of Pyrodinium bahamense var. compressum and the green Noctiluca scintillans used in the experiments

\begin{tabular}{|lc|}
\hline Species & $\begin{array}{c}\text { Carbon content }\left(\mathrm{ng} \mathrm{C} \text { cell }^{-1}\right) \\
\text { mean }( \pm \mathrm{SE} ; \mathrm{n})\end{array}$ \\
\hline $\begin{array}{l}\text { Pyrodinium bahamense } \\
\text { var. compressum } \\
\text { Noctiluca scintillans }\end{array}$ & $5.17(0.06 ; 4)$ \\
\hline
\end{tabular}

\section{Growth and ingestion of Noctiluca scintillans when fed Pyrodinium bahamense}

The growth of the green Noctiluca scintillans was studied at 2 irradiances, 45 and $150 \mu \mathrm{mol}$ photons $\mathrm{m}^{-2}$ $\mathrm{s}^{-1}$ (Figs. 4, 5 \& 6). In all cases, populations of N. scintillans grew exponentially for the first 10 to $14 \mathrm{~d}$ of incubation, regardless of whether or not food was supplied. However, growth subsequently stopped and the population declined in many cases for the re-

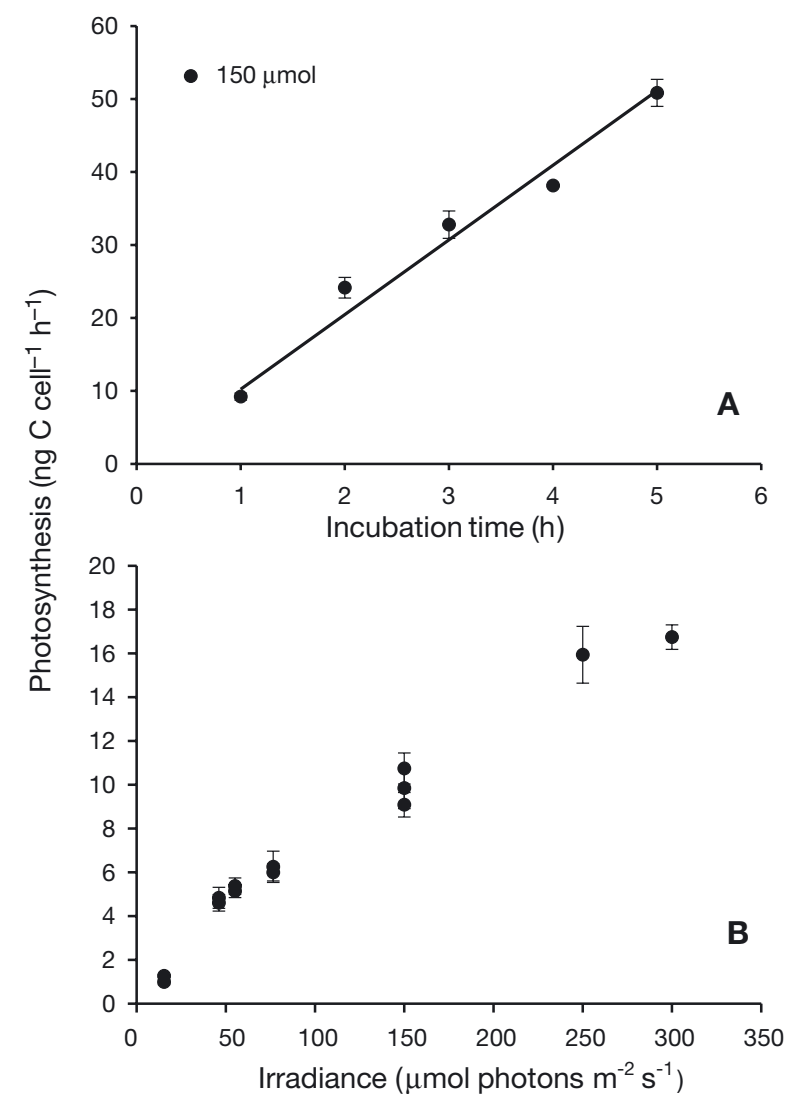

Fig. 3. Noctiluca scintillans. Photosynthetic performance of unfed individuals as a function of (A) incubation time at an irradiance of $150 \mu \mathrm{mol}$ photons $\mathrm{m}^{-2} \mathrm{~s}^{-1}$, (B) irradiance using $<3 \mathrm{~h}$ incubation time. Data points represent means $\pm 1 \mathrm{SE}$ $(\mathrm{n}=4)$. The line in $(A)$ represents a linear regression of all data points $\left(\mathrm{R}^{2}=0.98\right)$ mainder of the experimental period, irrespective of irradiance. Taking only data from the first $10 \mathrm{~d}$ of incubation into consideration, the growth rate of Noctiluca scintillans was 0.058 and $0.14 \mathrm{~d}^{-1}$ at irradiances of 45 and $150 \mu \mathrm{mol}$ photon $\mathrm{m}^{-2} \mathrm{~s}^{-1}$, respectively, when grown without prey. When supplied with Pyrodinium bahamense as food, the growth of $N$. scintillans increased with prey concentration without showing any signs of saturation (Fig. 6). At $45 \mu \mathrm{mol}$ photons $\mathrm{m}^{-2} \mathrm{~s}^{-1}$, the growth rate increased to $0.09 \mathrm{~d}^{-1}$ at an average prey concentration of 315 cells $\mathrm{ml}^{-1}\left(\sim 1550 \mu \mathrm{g} \mathrm{C}^{-1}\right)$, while the growth rate at an irradiance of $150 \mu \mathrm{mol}$ photons $\mathrm{m}^{-2} \mathrm{~s}^{-1}$ reached $0.25 \mathrm{~d}^{-1}$ at a prey concentration of 550 cells $\mathrm{ml}^{-1}$ $\left(\sim 2750 \mu \mathrm{g} \mathrm{C}^{-1}\right)$. A linear regression analysis of the data sets revealed a correlation coefficient $\left(R^{2}\right)$ of 0.90 and 0.59 , at irradiances of 150 and $45 \mu \mathrm{mol}$ photons $\mathrm{m}^{-2}$ $\mathrm{s}^{-1}$, respectively. A paired $t$-test revealed no significant difference in the slopes of the 2 regression lines ( $p>$ $0.05)$, and thus indicates that growth increase due to food uptake was not related to irradiance $(t$-test, $\mathrm{p}>$
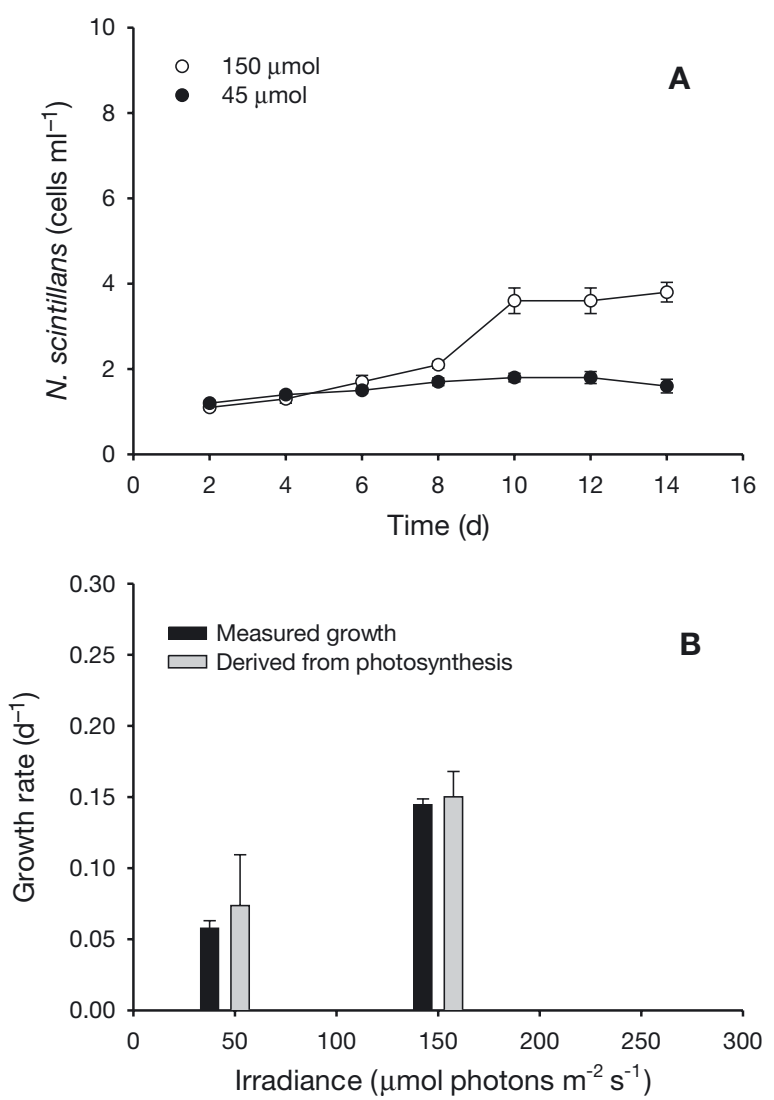

Fig. 4. Noctiluca scintillans. Unfed individuals. (A) Growth response as a function of incubation time at 2 irradiances: 45 and $150 \mu \mathrm{mol}$ photons $\mathrm{m}^{-2} \mathrm{~s}^{-1}$. (B) A Comparison of direct growth measurements, with growth rate estimates derived from measurements of photosynthesis assuming a photosynthetic growth yield of $50 \%$ 


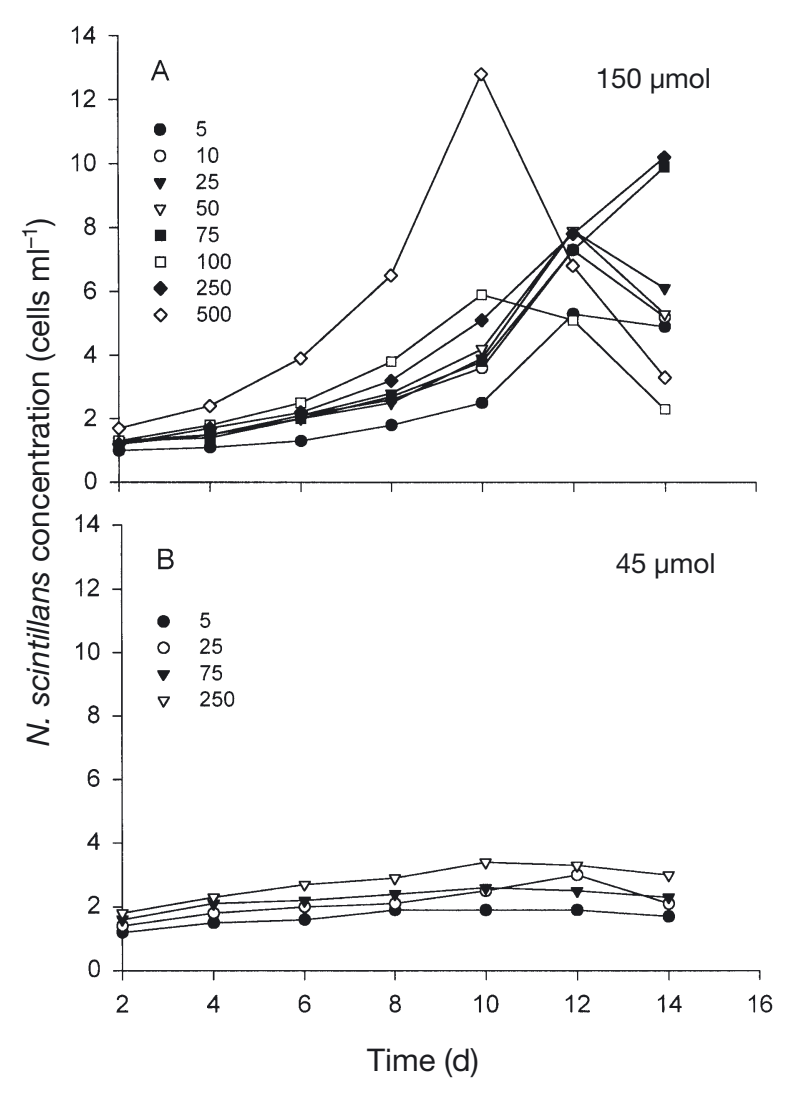

Fig. 5. Noctiluca scintillans. Growth/survival responses when fed different initial concentrations of Pyrodinium bahamense var. compressum at 2 irradiances: (A) 150 and (B) $45 \mu \mathrm{mol}$ photons $\mathrm{m}^{-2} \mathrm{~s}^{-1}$. Key shows concentrations of $P$. bahamense var. compressum in cells $\mathrm{ml}^{-1}$

0.05). Ingestion rates were only measured at $150 \mu \mathrm{mol}$ photons $\mathrm{m}^{-2} \mathrm{~s}^{-1}$ (Fig. 7). At this irradiance, the ingestion rate increased with prey concentration and showed no signs of saturation at prey concentrations below 540 $P$. bahamense cells $\mathrm{ml}^{-1}$.

The experimental data on ingestion, growth and photosynthesis carried out at an irradiance of $150 \mu \mathrm{mol}$ photons $\mathrm{m}^{-2} \mathrm{~s}^{-1}$ allow for a comparison of actually measured growth rates of Noctiluca scintillans with those that could be estimated from the photosynthesis and ingestion experiments. Assuming growth yields for photosynthesis and ingestion of 50 and $33 \%$, respectively (e.g. Hansen \& Nielsen 1997, Hansen et al. 2000), the measured rates of photosynthesis and ingestion can match the observed growth rates (Fig. 8). This makes it possible to compare the contribution of photosynthesis and ingestion to the growth the green $N$. scintillans. From this comparison, it is clear that the green. $N$. scintillans gains most of its growth from the photosynthesis of its endosymbionts at an irradiance of $150 \mu \mathrm{mol}$ photons $\mathrm{m}^{-2} \mathrm{~s}^{-1}$. At a prey concentration of $1450 \mu \mathrm{g} \mathrm{C} \mathrm{l}^{-1}$, ingestion only explained $20 \%$ of the

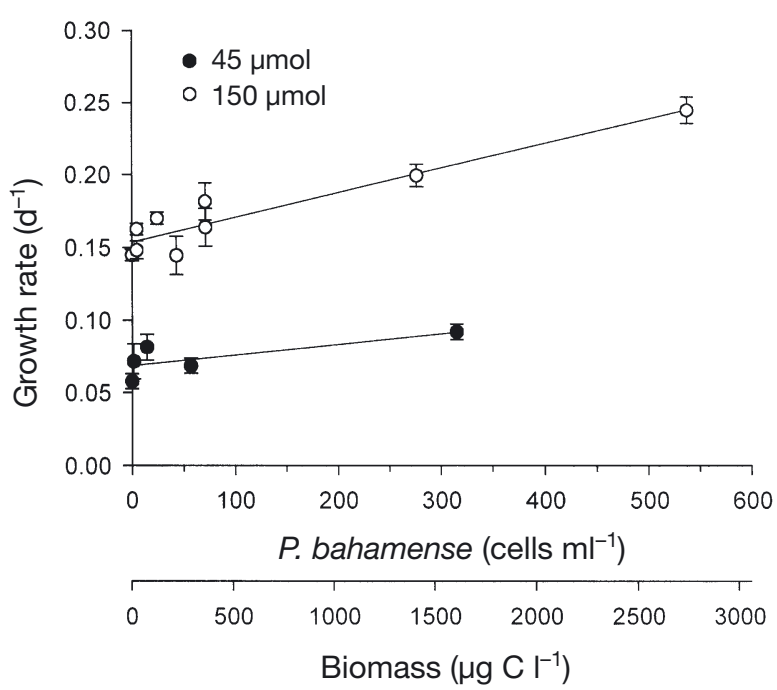

Fig. 6. Noctiluca scintillans. Growth rates as a function of the actual mean density in terms of both cell concentration (cells $\mathrm{ml}^{-1}$ ) and biomass ( $\mu \mathrm{g} \mathrm{C} \mathrm{l}^{-1}$ ) at 2 irradiances: 150 and $45 \mu \mathrm{mol}$ photons $\mathrm{m}^{-2} \mathrm{~s}^{-1}$

observed growth, while a prey concentration as high as $2750 \mu \mathrm{g} \mathrm{C} \mathrm{l}^{-1}$ was required for ingestion to explain $40 \%$ of the observed growth (Fig. 9).

The clearance of Noctiluca scintillans when fed Pyrodinium bahamense decreased only slightly with prey concentration, from $0.06 \mathrm{ml} \mathrm{cell}^{-1} \mathrm{~d}^{-1}$ at lowest prey concentrations to $0.03 \mathrm{ml} \mathrm{cell}^{-1} \mathrm{~d}^{-1}$ at very high prey concentrations (Fig. 10).

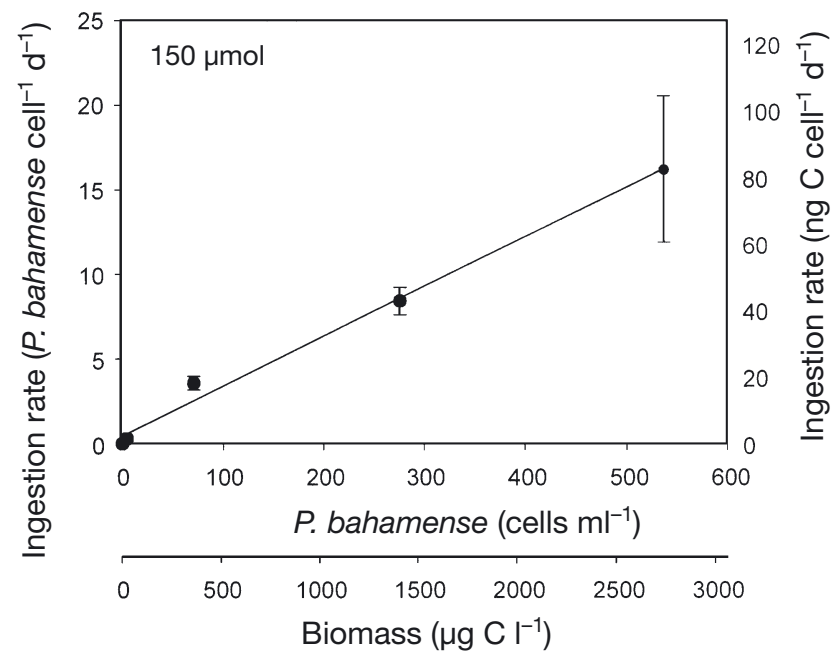

Fig. 7. Noctiluca scintillans. Ingestion rates as a function of Pyrodinium bahamense var. compressum concentration. Ingestion rates are given in both units of cells Noctiluca ${ }^{-1} \mathrm{~d}^{-1}$ (left $y$-axis) and biomass cell ${ }^{-1} \mathrm{~d}^{-1}$ (right $y$-axis). Values of prey concentration are given in both terms of cell concentration (cells $\mathrm{ml}^{-1}$ ) and biomass ( $\left.\mu \mathrm{g} \mathrm{Cl}^{-1}\right)$ 


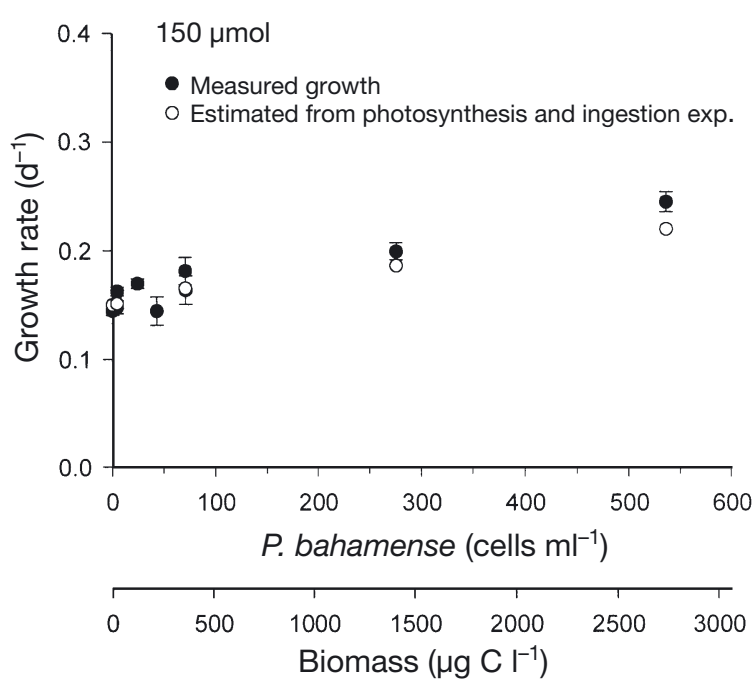

Fig. 8. Noctiluca scintillans. Growth rate $\left(\mathrm{d}^{-1}\right)$ as a function of prey concentration in cells $\mathrm{ml}^{-1}$ and biomass $\left(\mu \mathrm{g} \mathrm{Cl}^{-1}\right)$ when fed Pyrodinium bahamense var. compressum at an irradiance of $150 \mu \mathrm{mol}$ photons $\mathrm{m}^{-2} \mathrm{~s}^{-1}$. Growth rates derived from direct measurements of population growth (•) and from measurements of photosynthesis and ingestion rates (O), assuming a 50 and $33 \%$ growth yield for photosynthesis and ingestion, respectively

\section{DISCUSSION}

\section{Role of photosynthesis and food uptake on the growth of green Noctiluca scintillans}

In our experiments, the green Noctiluca scintillans grew in the light without the addition of prey, at least for a couple of weeks (Figs. 2 \& 5). This is in accordance with experiments carried out by Sweeny (1971), also on freshly collected green $N$. scintillans cells. Here, we demonstrated that the growth of green N. scintillans in monoculture increases with irradiance,

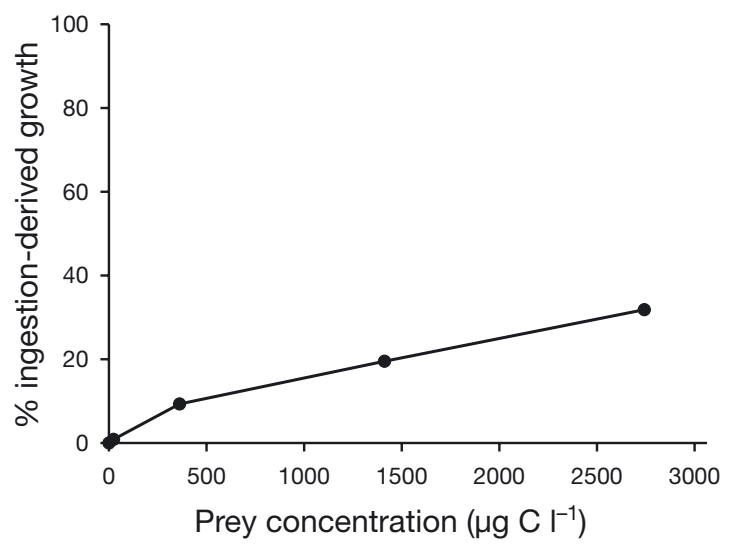

Fig. 9. Noctiluca scintillans. Percentage of growth obtained from ingestion as a function of Pyrodinium bahamense var. compressum concentration $\left(\mu \mathrm{g} \mathrm{C} \mathrm{l}^{-1}\right.$ ) assuming a $33 \%$ growth yield

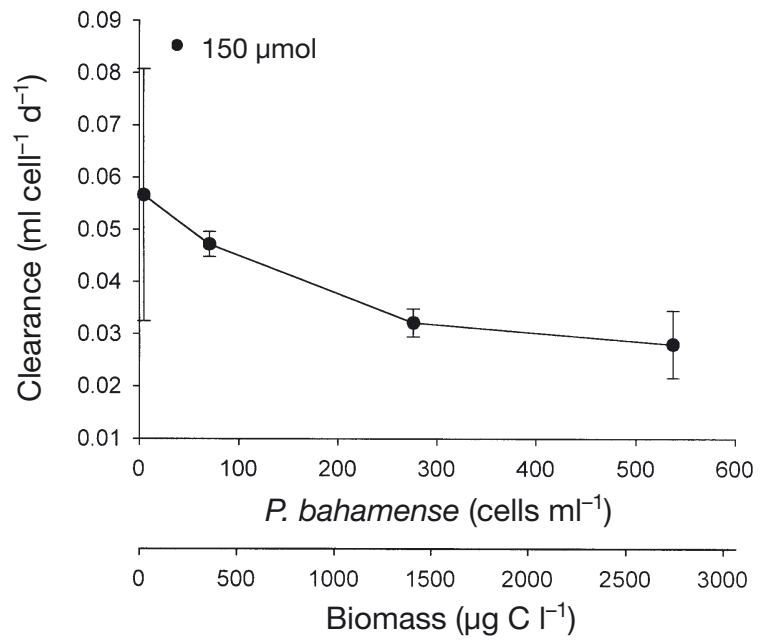

Fig. 10. Noctiluca scintillans. Clearance $\left(\mathrm{ml}\right.$ cell $\left.{ }^{-1} \mathrm{~d}^{-1}\right)$ as a function of Pyrodinium bahamense var. compressum concentration in terms of cell concentration (cells ml-1) and biomass $\left(\mu \mathrm{C}^{-1}\right)$

and that the increased growth could be explained by increased photosynthesis of its endosymbionts as irradiance increased (Fig. 4).

Sweeney (1971) observed the occasional presence of flagellates within small vacuoles in the cytoplasm of Noctiluca scintillans, suggesting the possibility of digestion of the endosymbionts by the host. However, according to her, food vacuoles were rarely seen. We looked for food vacuoles, but we observed no food vacuoles in $N$. scintillans cells when they were grown without the addition of prey. Thus, it seems most likely that the green $N$. scintillans largely depends on exudates from its endosymbionts, when grown in monoculture.

We fed 3 different prey items to the green Noctiluca scintillans and observed that it fed on all of them. The fastest growth rate of $N$. scintillans was achieved with the dinoflagellate Pyrodinium bahamense as prey, even though this species and isolate is known to produce saxitoxins (Oshima 1989). The addition of the other 2 algae, Akashiwo sanguinea (= Gymnodinium sanguineum) and Tetraselmis tetrahele, did lead to better growth compared to unfed controls, at least initially, but the rates were lower than with $P$. bahamense as prey. In fact, in the experiments in which $T$. tetrahele was used as prey, $N$. scintillans died out after $6 \mathrm{~d}$ of incubation, at which time the $T$. tetrahele population had become very dense (Fig. 2). T. tetrahele is not known to be toxic, and $N$. scintillans probably died out due to the development of very high $\mathrm{pH}$ in the dense mixed culture, caused by photosynthetic uptake of inorganic carbon (see Hansen 2002).

Even though Pyrodinium bahamense was the best of the 3 prey items tested, it only increased growth of the green Noctiluca scintillans by $\sim 0.1 \mathrm{~d}^{-1}$ at high prey 
concentrations. This might indicate that the green $N$. scintillans in nature primarily depends on the photosynthetic products from its endosymbionts. However, the growth rate of the red form of $N$. scintillans without endosymbionts has been shown to depend very much on the concentration, size and quality of the prey (Buskey 1995, Kiørboe \& Titelman 1998, Nakamura 1998). The highest growth rates $\left(>0.6 \mathrm{~d}^{-1}\right)$ have been obtained with diatoms and cryptophytes as prey, while intermediate growth rates $\left(0.1\right.$ to $\left.0.4 \mathrm{~d}^{-1}\right)$ typically have been obtained with dinoflagellates and other phytoflagellates as food. Algae, which do not support growth, or if they do it is only slight growth, are either very small phytoplankton species $(<4 \mu \mathrm{m})$ or species of a poor food quality. Thus, the maximum growth increase of the green $N$. scintillans due to food uptake of $\sim 0.1 \mathrm{~d}^{-1}$ found in the present study does not necessarily indicate that the green $N$. scintillans in nature will always primarily depend upon its endosymbionts. It is possible that higher growth rates could be obtained with prey other than those that we tested. The fact that food uptake in the green $N$. scintillans did not saturate even at very high concentrations of $P$. bahamense $\left(2750 \mu \mathrm{g} \mathrm{C}^{-1}\right)$ in our study supports this possibility. The best prey types for the red form of $N$. scintillans support maximum growth rates already at prey concentrations of between 500 and $1000 \mu \mathrm{g} \mathrm{C}^{-1}$ (Buskey 1995, Kiørboe \& Titelman 1998).

\section{Impact of the green Noctiluca scintillans on natural cell concentrations of Pyrodinium bahamense}

Gonzales (1989) was the first to observe that blooms of the green Noctiluca scintillans succeeded Pyrodinium bahamense blooms in Philippines waters. However, Azanza \& Miranda (2001) gave the first indication that the green $N$. scintillans might be an important grazer on P. bahamense blooms. According to their study, P. bahamense blooms in Manila Bay, Philippines usually takes place during the southwest monsoon (May to October), characterized by the onset of the rainy season after a warm, dry period. However, in $1998 P$. bahamense did not bloom. The reason for this is unknown, but the authors discovered that the green N. scintillans co-occurred with $P$. bahamense in May until about December of that year. This was unusual because the green $N$. scintillans is usually found in plankton samples in the dry Northeast monsoon from November to early March (Azanza \& Miranda 2001). Thus, they hypothesized that the reason why the $P$. bahamense failed to bloom that year at least partly was due to the success of N. scintillans.

Our grazing experiments revealed that the green Noctiluca scintillans can remove Pyrodinium beha- mense cells from the water column with a clearance rate of between 0.03 and $0.06 \mathrm{ml} \mathrm{N}$. scintillans $\mathrm{d}^{-1}$, depending upon the cell concentration of $P$. bahamense. This means that between 3 and $60 \%$ of the $P$. bahamense population potentially will be removed from the water column every day by the green $N$. scintillans when it occurs in cell concentrations of 1 and 10 cells $\mathrm{ml}^{-1}$, respectively. Therefore, even though grazing by $N$. scintillans on $P$. bahamense in most cases only contributes to a small fraction of the total carbon uptake of $N$. scintillans, it may still have a significant impact on dinoflagellate blooms in the area, such as $P$. bahamense blooms.

\section{Why does Noctiluca scintillans lose its endosymbionts in laboratory cultures?}

The green Noctiluca scintillans lost its endosymbionts after some time in our laboratory cultures under all culture conditions-an observation also made by Sweeney (1971). The fact that Pedinomonas noctilucae only has been found inside N. scintillans cells and that released cells do not survive for long in seawater or fresh water, not even at the low $\mathrm{pH}$ which is found inside N. scintillans cells (Sweeney 1971), indicates that the prasinophyte only can thrive inside $N$. scintillans cells. Therefore, an apparent unknown factor is lacking, which is essential for the growth of $P$. noctilucae and for a successful symbiosis between this species and $N$. scintillans. Most likely this growth factor derives from food ingested by N. scintillans.

Although many photosynthetic dinoflagellates are known to depend on external organic compounds (reviewed by Gaines \& Taylor 1987), only Gymnodinium gracilentum has so far been shown to acquire essential growth factors through ingestion of food (Skovgaard 2000). However, other examples of photosynthetic algae, which depend on growth factors derived from their prey, have been found among mixotrophic chrysophytes (Kimura \& Ishida 1985, 1989, Caron et al. 1993). Future work on N. scintillans is required to determine the nature of the growth factor and to study its role for the success of the green $N$. scintillans in nature.

\section{CONCLUSION}

The green Noctiluca scintillans is photosynthetically active and can grow for up to $2 \mathrm{wk}$ in the laboratory without the ingestion of food. We failed to grow the green $N$. scintillans with its endosymbionts for longer time periods, despite the fact that we fed it different prey types. Thus, symbiosis between the green 
N. scintillans and its endosymbionts seems to rely on a growth factor, which probably derives from the food it ingests. Future research is required to study the nature and role of the growth factor. We discovered that the green $N$. scintillans can feed on the toxic dinoflagellate Pyrodinium bahamense and utilize it as food for growth. Ingestion rates were, however, quite low, except at very high concentrations of $P$. bahamense. Despite this, our results suggest that the green $N$. scintillans, when it occurs in bloom concentrations, will have a substantial grazing impact on natural $P$. bahamense populations.

Acknowledgements. The research collaboration (including scientific visits of personnel) between the laboratories of P.J.H. and R.A. were made possible through the support of the International Atomic Energy Agency (IAEA). This paper is part of the results of the research program entitled 'Application of Nuclear Techniques to Address Specific Red Tide (Harmful Algal Bloom) Concerns', funded by the IAEA and Philippine Department of Science and TechnologyPhilippine Council for Aquatic and Marine Research and Development (DOST-PCAMRD). Estrelita D. Flores and Iris U. Baula assisted in the field and laboratory work.

\section{LITERATURE CITED}

Azanza RV, Miranda LN (2001) Phytoplankton composition and Pyrodinium bahamense toxic blooms in Manila Bay, Philippines. J Shellfish Res 20:1251-1255

Buskey EJ (1995) Growth and bioluminescence of Noctiluca scintillans on varying algal diets. J Plankton Res 17:29-40

Caron DA, Sanders RW, Lim EL, Marrasé C, Amaral LA, Whitney S, Aoki RB, Porter KG (1993) Light-dependent phagotrophy in the freshwater mixotrophic chrysophyte Dinobryon cylindricum. Microb Ecol 25:93-111

Chen H, Qi S (1991) The feeding and vegetative reproduction diurnal rhythms of Noctiluca scintillans. J Jinan Univ China 12:104-107

Corrales RA, Hall S (1993) Isolation and culture of Pyrodinium bahamense var. compressum from the Philippines. In: Smayda TJ, Shimizu Y (eds) Toxic phytoplankton blooms in the sea. Elsevier, Amsterdam, p 725-730

Corrales RA, Maclean JL (1995) Impacts of harmful algae on sea farming in the Asia-Pacific areas. J Appl Phycol 7: 151-162

Elbrächter M, Qi Y (1998) Aspects of Noctiluca (Dinophyceae) population dynamics. In: Anderson DM, Cembella A, Hallegraeff GM (eds) Physiological ecology of harmful algal blooms. NATO ASI Series, 41, Berlin, p 315-335

Enomoto Y (1956) On the occurrence and the food of Noctiluca scintillans (Macartney) in the waters adjacent to the west coast of Kyushu, with special reference to the possibility of the damage caused to the fish eggs by that plankton. Bull Jpn Soc Sci Fish 22:82-89

Gaines G, Taylor FJR (1987) Heterotrophic nutrition. In: Taylor FJR (ed) The biology of dinoflagellates. Botanical Monographs 21, Blackwell Scientific Publications, Oxford, p 224-268

Gonzales CL (1989) Pyrodinium blooms and paralytic shellfish poisoning in the Philippines. In: Hallegraeff GM, Maclean JL (eds) Biology, epdemiology and management of Pyrodinium red tides. ICLARM Conf Proc 21, Fisheries Department, Ministry of Development, Bandar Seri Begawan, and International Center for Aquatic Resources Management, Manila, p 39-47

Hansen PJ (2002) The effect of high pH on the growth and survival of marine phytoplankton: implications for species succession. Aquat Microb Ecol 28:279-288

Hansen PJ, Nielsen TG (1997) Mixotrophic feeding of Fragilidium subglobosum (Dinophyceae) on three species of Ceratium: effects of prey concentration, prey species and light intensity. Mar Ecol Prog Ser 147:187-196

Hansen PJ, Bjørnsen PK, Hansen B (1997) Zooplankton grazing and growth: scaling within the size range $2 \mu \mathrm{m}$ to $2000 \mu \mathrm{m}$. Limnol Oceanogr 42:687-704

Hansen PJ, Skovgaard A, Glud RN, Stoecker DK (2000) Physiology of the mixotrophic dinoflagellate Fragilidium subglobosum. II. Effects of time scale and prey concentration on photosynthetic performance. Mar Ecol Prog Ser 201:137-146

Jakobsen HH, Hansen PJ, Larsen J (2000) Growth and grazing responses of two chloroplast-retaining dinoflagellates: effect of irradiance and prey species. Mar Ecol Prog Ser 201:121-128

Kimura B, Ishida Y (1985) Photophagotrophy in Uroglena americana, Chrysophyceae. Jpn J Limnol 46:315-318

Kimura B, Ishida Y (1989) Phospholipid as a growth factor of Uroglena americana, a red tide Chrysophyceae in Lake Biwa. Nippon Suisan Gakkaishi 55:799-804

Kiørboe T, Titelman J (1998) Feeding, prey selection and prey encounter mechanisms in the heterotrophic dinoflagellate Noctiluca scintillans. J Plankton Res 20:1615-1636

Nakamura Y (1998) Growth and grazing of a large heterotrophic dinoflagellate, Noctiluca scintillans in laboratory cultures. J Plankton Res 20:1711-1720

Oshima Y (1989) Toxins in Pyrodinium bahamense var compressum and infested marine organisms. In: Hallegraeff GM, Maclean JL (eds) Biology, epidemiology and management of Pyrodinium red tides. ICLARM Conf Proc 21, Fisheries Department, Ministry of Development, Bandar Seri Begawan, and International Center for Aquatic Resources Management, Manila, p 73-79

Parsons TR, Maita Y, Lalli CM (1984) A manual of chemical and biological methods for seawater analysis. Pergamon Press, Oxford

Prasad R (1958) A note on the occurrence and feeding habits of Noctiluca and their effects on the plankton community and fisheries. Proc Indian Acad Sci B 47:331-337

Skovgaard A (2000) A phagotrophically derivable growth factor in the plastidic dinoflagellate Gyrodinium resplendens (Dinophyceae). J Phycol 36:1069-1078

Skovgaard A, Hansen PJ, Stoecker DK (2000) Physiology of the mixotrophic dinoflagellate Fragilidium subglobosum. I. Effects of phagotrophy and irradiance on photosynthesis and carbon content. Mar Ecol Prog Ser 201:129-136

Stoecker DK, Silver MW, Michaels AE, Davis LH (1988) Obligate mixotrophy in Laboea strobila, a ciliate which retains chloroplasts. Mar Biol 99:415-423

Sweeney BM (1971) Laboratory studies of a green Noctiluca from New Guinea. J Phycol 7:53-58

Sweeney BM (1976) Pedinomonas noctilucae (Prasinophyceae), the flagellate symbiotic in Noctiluca (Dinophyceae) in Southeast Asia. J Phycol 12:460-464

Submitted: September 24, 2003; Accepted: February 19, 2004 Proofs received from author(s): June 15, 2004 